\title{
Research frontiers in the analysis of coupled biogeochemical cycles
}

\author{
Adrien C Finzi ${ }^{1 *}$, Jonathan J Cole ${ }^{2}$, Scott C Doney ${ }^{3}$, Elisabeth A Holland ${ }^{4}$, and Robert B Jackson ${ }^{5}$
}

\section{B}

The analysis of coupled biogeochemical cycles (CBCs) addresses the scientific basis for some of today's major environmental problems. Drawing from information presented at a series of sessions on CBCs held at the 2009 Annual Meeting of the Ecological Society of America and from the research community's expertise, we identify several principal research themes that justify action and investment. Critical areas for research include: coupling of major element cycles to less studied yet equally important trace element cycles; analyzing CBCs across ecosystem boundaries; integrating experimental results into regional- and global-scale models; and expanding the analysis of human interactions with CBCs arising from human population growth, urbanization, and geoengineering. To advance the current understanding of $\mathrm{CBCs}$ and to address the environmental challenges of the 21st century, scientists must maintain and synthesize data from existing observational and experimental networks, develop new instrumentation networks, and adopt emerging technologies.

Front Ecol Environ 2011; 9(1): 74-80, doi:10.1890/100137 y identifying causal relationships and suggesting possible solutions, there is a clear role for the analysis of coupled biogeochemical cycles (CBCs) in addressing major environmental problems (eg Naylor et al. 1998; Schlesinger et al. 2011). For example, fossil-fuel combustion and land-use change have increased atmospheric carbon dioxide $\left(\mathrm{CO}_{2}\right)$ concentrations by nearly $40 \%$ since the beginning of the Industrial Revolution (Canadell et al. 2007), and reductions in greenhouse-gas (GHG) emissions are central to combating climate

\section{In a nutshell:}

- There is a clear role for the analysis of coupled biogeochemical cycles (CBCs) in addressing the scientific basis for major environmental problems, by both identifying causal relationships and suggesting possible solutions

- Frontiers for research in CBCs include coupling of major element cycles to less studied yet equally important trace element cycles, analyzing $\mathrm{CBCs}$ across ecosystem boundaries, and integrating information from experiments into regional- and global-scale models

- Human population growth, as well as geoengineering efforts aimed at mitigating climate change, are likely to accentuate present-day, anthropogenic changes to $\mathrm{CBCs}$

- Researchers will need to rely on available data from existing studies and experiments, develop new or expand existing instrumentation networks, incorporate emerging technologies in the analysis of CBCs, and work together with stakeholders and government agencies to address the environmental challenges posed by human alteration of CBCs, such as climate change and the sustainable management of lands and coastal oceans

${ }^{1}$ Department of Biology, Boston University, Boston, MA (afinzi@ bu.edu); ${ }^{2}$ Cary Institute of Ecosystem Studies, Millbrook, NY; ${ }^{3}$ Woods Hole Oceanographic Institution, Woods Hole, MA; ${ }^{4}$ National Center for Atmospheric Research, Boulder, CO; ${ }^{5}$ Department of Biology and Nicholas School of the Environment, Duke University, Durham, NC change. Similarly, the application of nitrogen $(\mathrm{N})$ and phosphorus $(\mathrm{P})$ fertilizers has increased agricultural productivity but simultaneously degraded environmental quality, to the point where fertilizer management is critical for maintaining ecosystem functions and services (Robertson and Vitousek 2009). Indeed, the biogeochemical research community has made great strides in understanding the individual and combined effects of different global changes on the structure and function of terrestrial and aquatic ecosystems (Likens 1992; Finzi et al. 2011). Biogeochemists increasingly recognize the importance of understanding how environmental problems involve changes in not one but multiple coupled element cycles, and how solutions to these problems require an explicit consideration of these couplings.

This Special Issue of Frontiers highlights some of the many advances in the field of CBCs. In this overview, we identify crosscutting themes from the papers included in this issue as well as from talks presented in a series of sessions and a workshop held at the 2009 Annual Meeting of the Ecological Society of America. Our goal is to highlight common research themes and discuss the platforms required to address questions that will yield important insights into the functioning of the Earth system from a biogeochemical perspective.

\section{Crosscutting themes in the analysis of CBCs}

Interactions among the $\mathrm{C}, \mathrm{N}$, and $\mathrm{P}$ cycles are among the best studied in the world, and for good reason. These three elements are intricately linked by the biochemistry of life and by the evolutionary and ecological consequences of different strategies for their acquisition, storage, and recycling (Sterner and Elser 2002). These element cycles' interactions will largely determine the effect of anthropogenic $\mathrm{CO}_{2}$ emissions on Earth's climate 
through their respective influences on carbon (C) removal from the atmosphere and storage on land and in the sea (Falkowski et al. 2000).

There are, however, many compelling examples of the ways in which the $\mathrm{C}, \mathrm{N}$, and $\mathrm{P}$ cycles are linked to other element cycles that are not so well understood (Burgin et al. 2011). For instance, nitrogenase - an enzyme that is central to the process of biological $\mathrm{N}_{2}$ fixation and hence the accrual of $\mathrm{N}$ in ecosystems - contains an iron (Fe)-molybdenum (Mo) cofactor. The availability of Fe and Mo limits the rate of biological $\mathrm{N}_{2}$ fixation in terrestrial and aquatic ecosystems (Coale et al. 1996; Mills et al. 2004; Barron et al. 2009). Because $N$ limitation is widespread in the biosphere, the Fe and Mo cycles indirectly control the $\mathrm{C}$ cycle in many places, through their effect on fixation and the availability of $\mathrm{N}$ that fuels primary production (Wang and Houlton 2009; Figure 1).

Although much is known about $\mathrm{N}_{2}$ fixation from fertilization experiments with $\mathrm{Fe}, \mathrm{Mo}$, and other trace metals (Boyd et al. 2007; Barron et al. 2009), outstanding questions remain. In oceanic systems, as an example, key areas for additional research include: the bioavailability of Fe in aerosol particles and dust; the effect of Fe and P limitation on $\mathrm{N}_{2}$ fixation rates; the community structure of diazotrophic organisms (Boyd and Ellwood 2010; Monteiro et al. 2010); and the effect of sulfate $\left(\mathrm{SO}_{4}{ }^{2-}\right)$ inhibition on Mo uptake, which may explain why $\mathrm{N}_{2}$ fixation proceeds more readily in fresh waters than in the ocean (Vitousek and Howarth 1991; Marino et al. 2003). Likewise, in terrestrial ecosystems, key areas for additional research include the link between the biogeography of symbiotic $\mathrm{N}_{2}$ plants and their effect on CBCs (Crews 1999), analysis of the spatial and temporal scales over which $\mathrm{P}$ and trace metal supplies constrain $\mathrm{N}_{2}$ fixation (Barron et al. 2009), and the effects of global change on symbiotic and asymbiotic $\mathrm{N}_{2}$ fixation (Wang and Houlton 2009).

Biogeochemical cycles are dynamic - with large exchanges of $\mathrm{C}$ and nutrients among terrestrial ecosystems, aquatic ecosystems, and Earth's atmosphere - and serve to connect ecosystems to one another. In general, however, the analysis of biogeochemical cycles has been disciplinary, often ignoring important cross-ecosystem linkages that affect ecosystem functioning. Streams, for instance, transport a substantial quantity of the $\mathrm{C}$ fixed through photosynthesis on land to the ocean and atmosphere (Cole et al. 1994), as well as N and P to the coastal ocean, which often contribute to eutrophication (Diaz and Rosenberg 2008).
Winds also transfer considerable quantities of terrestrially derived nutrients (eg P, Fe, Mo) - often critical for primary production - in dust to downwind ecosystems (Chadwick et al. 1999; Jickells et al. 2005). Furthermore, wildfires rapidly change the quantity of $\mathrm{C}, \mathrm{N}$, and $\mathrm{P}$ in biomass and soils, and the atmospheric transport of ash also delivers nutrients to downwind ecosystems (Raison et al. 1985). Yet analyzing $\mathrm{CBCs}$ across ecosystem boundaries provides the necessary context for understanding the emergence of particular patterns or processes in both the source and receiving ecosystem (Figure 2).

Our understanding of CBCs, albeit incomplete, can be used as a powerful constraint on model analysis. Plot- to regional-scale terrestrial models and a number of oceanic models explicitly include the coupled cycles of $\mathrm{C}, \mathrm{N}$, and/or $\mathrm{P}$, and these couplings affect the projected magnitude of climate change with rising atmospheric $\mathrm{CO}_{2}$ concentrations (Parton et al. 1987; Rastetter 2011). In terrestrial ecosystems, several models developed in the early 1990s predicted that nutrient limitation would preclude a long-term response of terrestrial productivity to rising atmospheric $\mathrm{CO}_{2}$ (eg Comins and McMurtrie 1993), an observation borne out by several (eg Reich et al. 2006), though not all (eg McCarthy et al. 2010), long-term $\mathrm{CO}_{2}$ enrichment experiments. In contrast, biogeochemical constraints are not used as effectively in larger-scale 


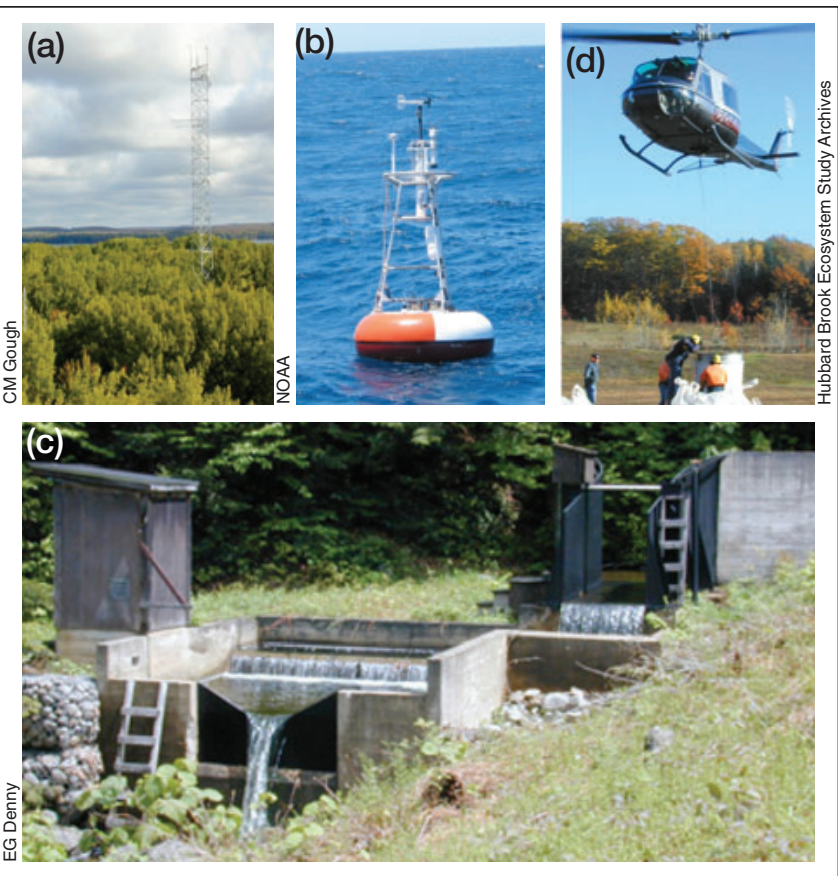

Figure 2. Research in $\mathrm{CBCs}$ requires integrative research platforms and whole-ecosystem approaches. Flux towers in terrestrial systems (a), as well as in lakes and the ocean (b), provide continuous high-frequency measurements of carbon (C) and water (in the form of vapor) exchanges between the ecosystem and the atmosphere. These exchanges are routinely used to calculate primary production and $\mathrm{C}$ sequestration on land, in lakes and rivers, and in the sea. (c) The water leaving a watershed bears a biogeochemical signature of the processes occurring in vegetation, soils, and the stream itself. The most successful research networks will couple experiments, such as the addition of calcium $(\mathrm{Ca})$ to the Hubbard Brook Experimental Forest (d), with the data collected from long-term observational networks (eg $[a]$ and $[b])$. This approach ensures that the patterns observed and processes inferred by sensor networks are explained in clear, cause-and-effect terms that can and should be incorporated into prognostic models.

models. Biogeochemical feedbacks to $\mathrm{C}$ storage in the terrestrial biosphere are only now being incorporated into global-scale climate-C-cycle models, many of which are used in Intergovernmental Panel on Climate Change reports to predict the future state of the $\mathrm{C}$ cycle and hence Earth's future climate (Thornton et al. 2007; Bonan and Levis 2010; Zaehle et al. 2010), even though the importance of $\mathrm{CBC}$ constraints at the global scale has long been known (Melillo et al. 1993). Failure to include CBCs in models, even in their simplest form (eg the stoichiometry of $\mathrm{C}, \mathrm{N}$, and $\mathrm{P}$ in organisms), appears to overestimate the 21st-century terrestrial C sink (Hungate et al. 2003) and thus underestimate the degree of projected warming during this period. A recent analysis by Wang and Houlton (2009) suggested that the degree of warming by 2100 depends on the interactive effects of climate, $\mathrm{P}$ supply, and biological $\mathrm{N}_{2}$ fixation on primary production.

\section{Humans and CBCs}

The growth of the human population to date has yielded cities of unprecedented size and form (Schneider and Woodcock 2008), which have modified biogeochemical cycles (Kaye et al. 2006) and altered climate (Zhang et al. 2004). In 2008, about half of the world's population lived in urban areas; by 2050 , about $70 \%$ of the human population is projected to live in urban environments (UNFPA 2007). Yet we are only beginning to understand how large population centers affect $\mathrm{CBCs}$ over local and regional scales. How does the importation of food, energy, and building materials affect the stoichiometry and cycling of $\mathrm{C}, \mathrm{N}, \mathrm{P}$, and water in urban and suburban regions, and how might the types of landscapes and seascapes surrounding these regions modulate the downwind and downstream effects of these changes? To what extent could urban planning help mitigate some of these effects (Pataki et al. 2011)? Integrated assessment models are starting to address these questions (Wise et al. 2009) and will contribute to a better understanding of the impacts of urbanization on CBCs, particularly in parts of the world such as developing nations - where urbanization is expected to increase the most.

An emerging human interest, geoengineering, has substantial implications for CBCs (Figure 3). Defined as deliberately modifying Earth's environment to mitigate the effect of increasing GHG concentrations on the climate system, geoengineering options are increasingly being proposed as a bridge to a carbon-neutral future (eg Jackson and Salzman 2010; Keith et al. 2010). One set of geoengineering activities seeks to cool the Earth by removing $\mathrm{CO}_{2}$ and other GHGs from the atmosphere by planting trees, fertilizing the ocean with $\mathrm{Fe}$, or capturing and storing $\mathrm{CO}_{2}$ at power plants. A second set of geoengineering activities proposes to cool the planet by blocking or reflecting sunlight; such "sunshade" approaches include injecting dust into the stratosphere or increasing the cover or brightness of clouds to compensate for GHG-associated warming (Crutzen 2006).

Most geoengineering approaches will alter CBCs, even those intended to manipulate the physical rather than the biological environment. For instance, sunshades that block or reflect sunlight are almost certain to reduce precipitation globally. The eruption of Mount Pinatubo in the Philippines in 1991 provided an interesting analog; large emissions of aerosols - particles that reflect incoming sunlight back to space - to the atmosphere both cooled the Earth by $\sim 0.5^{\circ} \mathrm{C}$ for a year and produced a record decrease in runoff and river discharge into the oceans (Trenberth and Dai 2007). Global trends are not, however, the best gauge of sunshade efficacy or impact. One recent analysis suggested that sunshades cannot simultaneously stabilize temperature and precipitation in the face of continued GHG emissions (Ricke et al. 2010), and that the climate-trajectory response to solar-radiation management is likely to differ substantially from region to region. Because biogeochemical cycles are strongly influenced by 
temperature and precipitation, sunshades may alter CBCs in a manner that raises serious legal, ethical, and political concerns over their use. Food security may be particularly problematic, given the direct negative impact of reduced precipitation on crop productivity and decomposition, which releases essential supplies of $\mathrm{N}, \mathrm{P}$, and micronutrients to crops (St Clair and Lynch 2010).

Another geoengineering-related uncertainty is the extent to which these activities will alter emissions of trace gases as a result of changing CBCs. The oceans are currently a large natural sink for anthropogenic atmospheric $\mathrm{CO}_{2}$ resulting from the burial of $\mathrm{C}$ fixed by phytoplankton at great depths in the ocean. Geoengineering in the oceans seeks to amplify biological $\mathrm{C}$ export from the surface ocean by adding Fe to high nitrate, low chlorophyll equatorial and subpolar ecosystems (Boyd et al. 2007; Buesseler et al. 2008). More recent proposals involve adding Fe or P (the latter via enhanced upwelling) to subtropical low nitrate, low chlorophyll ecosystems to increase rates of $\mathrm{N}_{2}$ fixation by cyanobacteria (Karl and Letelier 2008). The tradeoff, however, may be enhancements in the release of nitrous oxide $\left(\mathrm{N}_{2} \mathrm{O}\right)$ - a GHG 310 times as powerful as $\mathrm{CO}_{2}$ - as a consequence of the increase in $\mathrm{N}_{2}$ fixation. Large-scale but short-term Fe fertilization experiments have found negligible to small increases in $\mathrm{N}_{2} \mathrm{O}$ production in the oceans. In contrast, model simulations of the longterm effects of Fe fertilization suggest that net emissions of $\mathrm{N}_{2} \mathrm{O}$ may increase substantially, reducing the climate benefits of any additional $\mathrm{C}$ sequestered in the ocean (Law 2008). Similarly, Fe fertilization experiments have revealed strong regional differences in dimethylsulfide (DMS) emissions from the ocean (Turner et al. 2004; Levasseur et al. 2006). DMS emissions may cool the planet through oxidation to sulfate aerosol particles that have sunshade-like effects and increase cloud cover by serving as cloud condensation nuclei.

The various geoengineering options that might be available to policy makers (eg Buesseler et al. 2008)
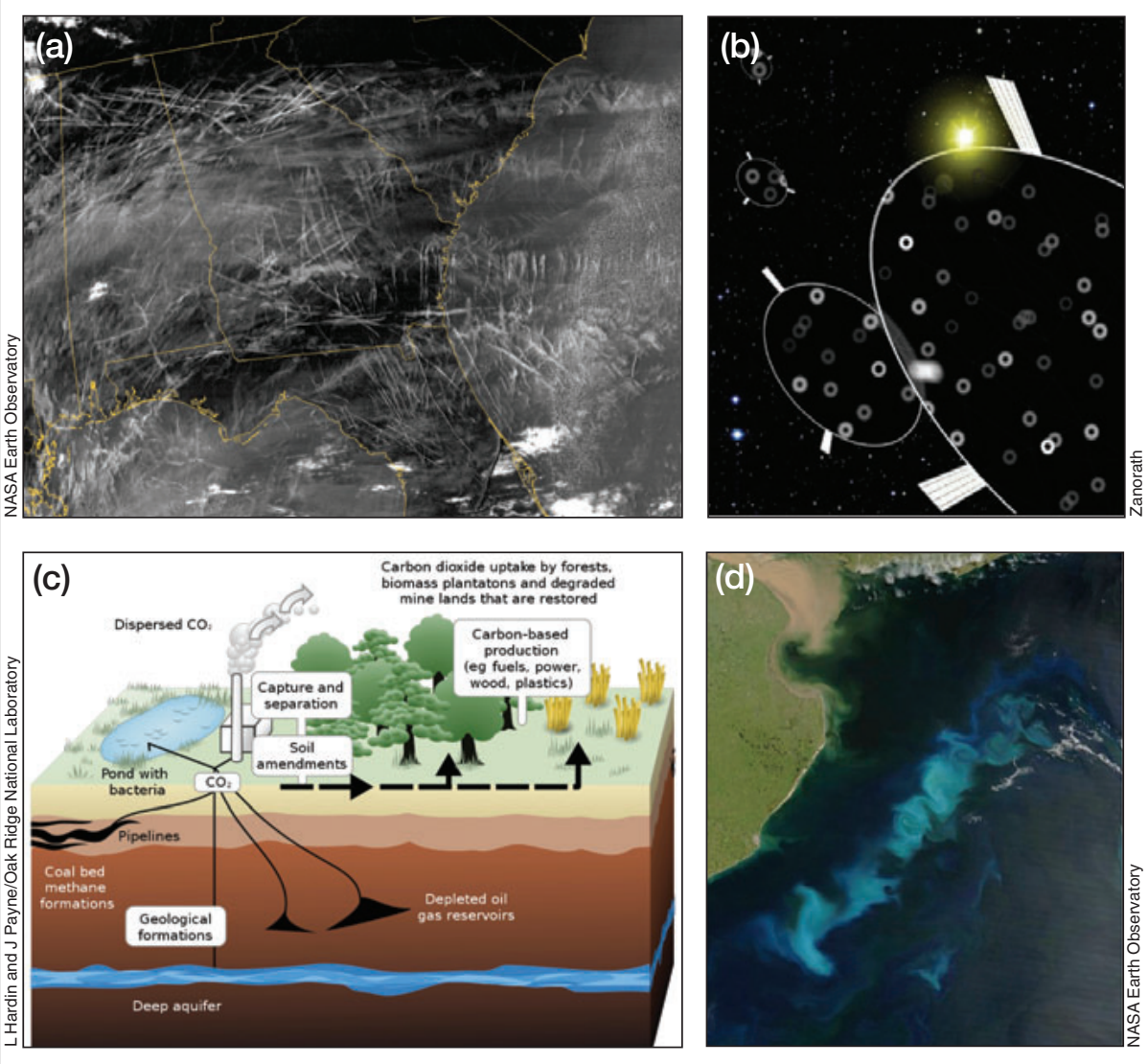

Figure 3. Examples of the geoengineering activities intended to mitigate the effect of increasing greenhouse-gas concentrations in the atmosphere. (a) NASA's Moderate Resolution Imaging Spectroradiometer (MODIS) tracking of airplane contrails generated by air traffic over the southeastern US on 29 January 2004. The whit irfaces of clouds reflect energy back to space. One "sunshade" scheme proposes to release sulfur into the atmosphere by aircraft. Sulfur particles are highly reflective and comit incoming energy from the Sun, showing how Schematic showing both terrestrial and geological sequestration of $\mathrm{CO}_{2}$ emissions from a coal-fired plant. (d) Phytoplankton bloom in the South Atlantic Ocean, off the coast of Argentina, captured by the MODIS on NASA's Aqua satellite. Phytoplankton growth in the open ocean is commonly Fe limited, so one set of geoengineering schemes proposes to fertilize the ocean in the hope of stimulating $\mathrm{C}$ uptake by photosynthesis and $\mathrm{C}$ storage as dead phytoplankton fall deep in the ocean.

need to be thoroughly analyzed in the framework of CBCs before implementation. Uncertainties in sunshade effects are mirrored in geoengineering activities seeking to remove $\mathrm{CO}_{2}$ from the atmosphere. Tree planting and bioenergy generation coupled to $\mathrm{C}$ capture and storage will require ecological footprints of millions of hectares of land to provide a meaningful solution (Jackson et al. 2008). Where will the N, P, and other elements needed for these options come from, and how will this affect CBCs in target and non-target ecosystems? Integrative research and novel synthesis of existing studies on CBCs will be vital in identifying the most constructive geoengineering approaches to climate change. 


\section{Research needs}

The maintenance and synthesis of data from existing observational and experimental networks (OENs), the development of new OENs, and the use of emerging technologies will be fundamental to advancing our understanding of CBCs and addressing key 21st-century challenges, including climate change, the growing human population, and the sustainable management of the land surface and coastal ocean (Melack et al. 2011). OENs are more than databases, technology, and hardware, however, and future advances in $\mathrm{CBC}$ analysis hinge on new modes of organizing and promoting observational and experimental science to address increasingly complex questions. This necessitates an improved culture of data sharing, which can only be achieved when researchers are given appropriate credit and incentives for their achievements through more recognized procedures for citing data packages and valuing coauthorship on papers involving large data compilations and numerous contributors.

Characterizing fine spatial and temporal resolution changes in the pools of elements such as $\mathrm{N}, \mathrm{P}, \mathrm{Fe}$, and sulfur (S), among others, remains a major challenge for biogeochemical research, particularly on land and in the open ocean but probably less so for the water and C cycles. The widespread deployment of high-temporalresolution $\mathrm{CO}_{2}$ and water (eg vapor, soil moisture) analyzers has yielded large volumes of data that have been essential in constraining global-scale, coupled climateC-cycle models (IPCC 2007). By contrast, analysis of N, $\mathrm{P}, \mathrm{Fe}$, and $\mathrm{S}$ is not typically automated; these elements require manual sampling and laboratory analysis. This results in generally less data on important element cycles and thus less information to constrain models. It is therefore critical to develop networks that measure in situ concentrations and isotopic compositions of elements and molecules in addition to $\mathrm{C}$ and water. To this end, there are encouraging developments. For example, several floats in the global Argo profiling float system, a network of $>3200$ free-floating temperature and salinity sensors, will begin measuring $\mathrm{O}_{2}, \mathrm{~S}^{2-}$, and $\mathrm{NO}_{3}^{-}$concentrations in seawater (Johnson et al. 2009). This added biogeochemical capacity will address unresolved issues in the size and distribution of oxygen minimum zones in the ocean, the nutrient content of sub-Antarctic mode water (water that is formed on the northern flank of the Antarctic Circumpolar Current and that fuels primary production in the oceans north of $30^{\circ} \mathrm{S}$ ), and the role of $\mathrm{CBCs}$ in the draw-down of surface water $\mathrm{CO}_{2}$ at the subtropical-subpolar boundary in the Pacific Ocean (Johnson et al. 2009).

Collaboration between biogeochemists and engineers to develop next-generation measurement and modeling technologies and to resolve issues associated with new applications of existing technology - is also necessary. For example, analysis of CBCs in soils and sediments requires the destructive removal of samples by coring, thereby pre- cluding repeated measurements and, through time, potentially compromising the integrity of the field site. Laserinduced breakdown spectroscopy (LIBS) is an emerging technology that may help to resolve this problem (Harmon et al. 2005). In LIBS, a pulsed laser operating over time scales measured in nanoseconds is inserted into the ground and heats a mineral or organic matter surface by $>10000 \mathrm{~K}$ to yield a sub-microgram plasma. During plasma formation, electrons recombine with ions and release energy in the 280-980 nm range, with emission spectra reflecting the types of elements and molecules present in the sample (Harmon et al. 2005). In laboratory applications, LIBS can have a field of view as small as $0.05 \mu \mathrm{m}^{2}$, allowing for the analysis of organic compounds within microbial cells (Morel et al. 2003; Rehse et al. 2010). In the field, LIBS has been used primarily for geochemical exploration, but the analysis of mineral composition at very fine spatial and temporal scales is clearly relevant to CBCs, particularly with respect to rock-derived nutrients.

The creation and maintenance of OENs requires secure sources of uninterrupted funding. But maintaining studies over many years to decades is complicated by the current funding structure, which often favors projects investigating new hypotheses at the expense of maintaining long-term studies, which often document unexpected events and provide important insights into the process underlying these events. In the recent past, longterm studies have relied to a greater extent on a creative patchwork of funding approaches (Keeling 1998). One solution - similar to what has been accomplished with most weather and stream chemistry data - is to transition the mode of some long-term observations from specific principal-investigator-driven research projects to routine monitoring conducted by more operational science agencies. Yet this strategy raises issues with respect to data quality, continuity, and ongoing engagement with the scientific community.

\section{Conclusions}

Whatever the scientific backdrop - geoengineering, landuse change, fertilizer management, climate change human activity is clearly altering CBCs, with important environmental consequences. The prospects for addressing these inherently complex issues from a scientific perspective certainly seem to be improving; data synthesis and data-model activities are expanding in both number and scope (eg Mayorga et al. 2010), new OENs are being established (eg Keller et al. 2008), and the biogeochemistry research community is increasingly using innovative ways to address long-standing questions about $\mathrm{CBCs}$ (eg Whiteside et al. 2009). As societies grow and progress, it will be necessary not only to tackle these questions, but also to remain flexible, so that the underlying principles in biogeochemistry can be applied to emerging environmental problems (eg those involving nanomaterials or geoengineering schemes) and that courses of action may 
be suggested to remediate negative effects before they reach a state of crisis.

\section{Acknowledgements}

We thank the National Science Foundation (NSF) and the Ecological Society of America (ESA) for their financial and logistical support of the Coupled Biogeochemical Cycles sessions held at the 2009 ESA Annual Meeting, and the publication of this special feature issue of Frontiers. The ideas presented in this paper are also the result of funding agency support for each author's research programs. ACF was supported by the NSF (DEB0743564) and the US Department of Energy's (DOE's) Office of Biological and Environmental Research (10DOE-1053) and would like to thank L Hutyra and N Phillips for discussions on urbanization and CBCs. SCD was supported by the Center for Microbial Oceanography, Research and Education (NSF EF-0424599). RBJ was supported by the NSF (DEB \#0717191) and by the DOE's National Institute for Climate Change Research.

\section{References}

Barron AR, Wurzburger N, Bellenger JP, et al. 2009. Molybdenum limitation of asymbiotic nitrogen fixation in tropical forest soils. Nat Geosci 2: 42-45.

Bonan GB and Levis S. 2010. Quantifying carbon-nitrogen feedbacks in the Community Land Model (CLM4). Geophys Res Lett 37: L07401, doi:10.1029/2010GL042430.

Boyd PW and Ellwood MJ. 2010. The biogeochemical cycle of iron in the ocean. Nat Geosci 3: 675-82.

Boyd PW, Jickells T, Law CS, et al. 2007. Mesoscale iron enrichment experiments 1993-2005: synthesis and future directions. Science 315: 612-17.

Buesseler KO, Doney SC, Karl DM, et al. 2008. Ocean iron fertilization - moving forward in a sea of uncertainty. Science 319: 162.

Burgin A, Yang W, Hamilton SK, and Silver W. 2011. Beyond C and $\mathrm{N}$ : how the microbial energy economy couples elemental cycles in diverse ecosystems. Front Ecol Environ 9: 44-52.

Canadell JG, Le Quéré C, Raupach MR, et al. 2007. Contributions to accelerating atmospheric $\mathrm{CO}_{2}$ growth from economic activity, carbon intensity, and efficiency of natural sinks. P Natl Acad Sci USA 104: 18866-70.

Chadwick OA, Derry LA, Vitousek PM, et al. 1999. Changing sources of nutrients during four million years of ecosystem development. Nature 397: 491-97.

Coale KH, Johnson KS, Fitzwater SE, et al. 1996. A massive phytoplankton bloom induced by an ecosystem-scale iron fertilization experiment in the equatorial Pacific Ocean. Nature 383: 495-501.

Cole JJ, Caraco NF, Kling GW, and Kratz TK. 1994. Carbon dioxide supersaturation in the surface waters of lakes. Science 265: $1568-70$.

Comins HN and McMurtrie RE. 1993. Long-term response of nutrient-limited forests to $\mathrm{CO}_{2}$ enrichment: equilibrium behavior of plant-soil models. Ecol Appl 3: 666-81.

Crews TE. 1999. The presence of nitrogen fixing legumes in terrestrial communities: evolutionary vs ecological considerations. Biogeochemistry 46: 233-46.

Crutzen PJ. 2006. Albedo enhancement by stratospheric sulfur injections: a contribution to resolve a policy dilemma? Climatic Change 77: 211-19.
Diaz RJ and Rosenberg R. 2008. Spreading dead zones and consequences for marine ecosystems. Science 321: 926-29.

Falkowski P, Scholes RJ, Boyle E, et al. 2000. The global carbon cycle: a test of our knowledge of Earth as a system. Science 290: 291-96.

Finzi A, Austin A, Cleland E, et al. 2011. Responses and feedbacks of coupled biogeochemical cycles to climate change: examples from terrestrial ecosystems. Front Ecol Environ 9: 61-67.

Harmon RS, De Lucia FC, Miziolek AW, et al. 2005. Laser-induced breakdown spectroscopy (LIBS) - an emerging field-portable sensor technology for real-time, in-situ geochemical and environmental analysis. Geochem-Explor Env A 5: 21-28.

Hungate BA, Dukes JS, Shaw MR, et al. 2003. Nitrogen and climate change. Science 302: 1512-13.

IPCC (Intergovernmental Panel on Climate Change). 2007. Climate change 2007: mitigation of climate change. In: Metz B, Davidson OR, Bosch PR, et al. (Eds). Contribution of Working Group III to the Fourth Assessment Report of the Intergovernmental Panel on Climate Change. Cambridge, UK, and New York, NY: Cambridge University Press.

Jackson RB, Randerson JT, Canadell JG, et al. 2008. Protecting climate with forests. Environ Res Lett 3, doi:10.1088/1748-9326/ 3/4/044006.

Jackson RB and Salzman J. 2010. Pursuing geoengineering for atmospheric restoration. Issues Sci Technol 24: 67-76.

Jickells TD, An ZS, Andersen KK, et al. 2005. Global iron connections between desert dust, ocean biogeochemistry, and climate. Science 308: 67-71.

Johnson KS, Berelson WM, Boss ES, et al. 2009. Observing biogeochemical cycles at global scales with profiling floats and gliders: prospects for a global array. Oceanography 22: 216-25.

Karl DM and Letelier RM. 2008. Nitrogen fixation-enhanced carbon sequestration in low nitrate, low chlorophyll seascapes. Mar Ecol-Prog Ser 364: 257-68.

Kaye JP, Groffman PM, Grimm NB, et al. 2006. A distinct urban biogeochemistry? Trends Ecol Evol 21: 192-99.

Keeling CD. 1998. Rewards and penalties of monitoring the Earth. Annu Rev Energ Env 23: 25-82.

Keith DW, Parson E, and Morgan MG. 2010. Research on global sun block needed now. Nature 463: 426-27.

Keller M, Schimel DS, Hargrove WW, and Hoffman FM. 2008. A continental strategy for the National Ecological Observatory Network. Front Ecol Environ 6: 282-84.

Law CS. 2008. Predicting and monitoring the effects of large-scale ocean iron fertilization on marine trace gas emissions. Mar EcoProg Ser 364: 283-88.

Levasseur M, Scarratt MG, Michaud S, et al. 2006. DMSP and DMS dynamics during a mesoscale iron fertilization experiment in the Northeast Pacific - part I: temporal and vertical distributions. Deep-Sea Res Pt I 53: 2353-69.

Likens GE. 1992. The ecosystem approach: its use and abuse. Oldendorf/Luhe, Germany: Ecology Institute.

Marino R, Howarth RW, Chan F, et al. 2003. Sulfate inhibition of molybdenum-dependent nitrogen fixation by planktonic cyanobacteria under seawater conditions: a non-reversible effect. Hydrobiologia 500: 277-93.

Mayorga E, Seitzinger SP, Harrison JA, et al. 2010. Global nutrient export from WaterSheds 2 (NEWS 2): model development and implementation. Environ Modell Softw 25: 837-53.

McCarthy HR, Oren R, Johnsen KH, et al. 2010. Re-assessment of plant carbon dynamics at the Duke free-air $\mathrm{CO}_{2}$ enrichment site: interactions of atmospheric $\mathrm{CO}_{2}$ with nitrogen and water availability over stand development. New Phytol 185: 514-28.

Melack J, Finzi A, Siegel D, et al. 2011. New ways of seeing and measuring ecosystems advance understanding of biogeochemical cycles. Front Ecol Environ 9: 37-43.

Melillo JM, McGuire AD, Kicklighter DW, et al. 1993. Global climate change and terrestrial net primary production. Nature 363: 234-40. 
Mills MM, Ridame C, Davey M, et al. 2004. Iron and phosphorus co-limit nitrogen fixation in the eastern tropical North Atlantic. Nature 429: 292-94.

Monteiro FM, Follows MJ, and Dutkiewicz S. 2010. Distribution of diverse nitrogen fixers in the global ocean. Global Biogeochem Cy 24: GB3017, doi:10.1029/2009GB003731.

Morel S, Leone N, Adam P, and Amouroux J. 2003. Detection of bacteria by time-resolved laser-induced breakdown spectroscopy. Appl Optics 42: 6184-91.

Naylor RL, Goldburg RJ, Mooney H, et al. 1998. Ecology: nature's subsidies to shrimp and salmon farming. Science 282: 883-84.

Pataki D, Carriero M, Cherrier J, et al. 2011. Coupling biogeochemical cycles in urban environments: ecosystem services, green solutions, and misconceptions. Front Ecol Environ 9: 27-36.

Parton WJ, Schimel DS, Cole CV, and Ojima DS. 1987. Analysis of the factors controlling soil organic matter levels in Great Plains grasslands. Soil Sci Soc Am J 51: 1173-79.

Raison RJ, Khanna PK, and Woods PV. 1985. Mechanisms of element trasnfer to the atmosphere during vegetation fires. Can J Forest Res 15: 132-40.

Rastetter EB. 2011. Modeling coupled biogeochemical cycles. Front Ecol Environ 9: 68-73.

Rehse SJ, Mohaidat QI, and Palchaudhuri S. 2010. Towards the clinical application of laser-induced breakdown spectroscopy for rapid pathogen diagnosis: the effect of mixed cultures and sample dilution on bacterial identification. Appl Optics 49: C27-35.

Reich PB, Hobbie SE, Lee T, et al. 2006. Nitrogen limitation constrains sustainability of ecosystem response to $\mathrm{CO}_{2}$. Nature 440: 922-25.

Ricke KL, Morgan MG, and Allen MR. 2010. Regional climate response to solar-radiation management. Nat Geosci 3: 537-41.

Robertson GP and Vitousek PM. 2009. Nitrogen in agriculture: balancing the cost of an essential resource. Annu Rev Env Resour 34: 97-125.

Schlesinger W, Cole J, Finzi A, and Holland E. 2011. Introduction to coupled biogeochemical cycles. Front Ecol Environ 9: 5-8.

Schneider A and Woodcock CE. 2008. Compact, dispersed, fragmented, extensive? A comparison of urban growth in twentyfive global cities using remotely sensed data, pattern metrics and census information. Urban Stud 45: 659-92.

St Clair S and Lynch J. 2010. The opening of Pandora's box: climate change impacts on soil fertility and crop nutrition in developing countries. Plant Soil 335: 101-15.

Sterner RW and Elser JJ. 2002. Ecological stoichiometry: the biology of elements from molecules to the biosphere. Princeton, NJ: Princeton University Press.

Thornton PE, Lamarque JF, Rosenbloom NA, and Mahowald NM. 2007. Influence of carbon-nitrogen cycle coupling on land model response to $\mathrm{CO}_{2}$ fertilization and climate variability. Global Biogeochem Cy 21: GB4018, doi:10.1029/2006GB002868.

Trenberth KE and Dai A. 2007. Effects of Mount Pinatubo volcanic eruption on the hydrological cycle as an analog of geoengineering. Geophys Res Lett 34: L15702, doi:10.1029/2007 GL030524.

Turner SM, Harvey MJ, Law CS, et al. 2004. Iron-induced changes in oceanic sulfur biogeochemistry. Geophys Res Lett 31: L14307, doi:10.1029/2004GL020296.

UNFPA (UN Population Fund). 2007. State of the world population. New York, NY: UNFPA. www.unfpa.org/swp/swpmain. htm. Viewed 12 Oct 2010.

Vitousek PM and Howarth RW. 1991. Nitrogen limitation on land and in the sea: how can it occur? Biogeochemistry 13: 87-115.

Wang YP and Houlton BZ. 2009. Nitrogen constraints on terrestrial carbon uptake: implications for the global carbon-climate feedback. Geophys Res Lett 36: L24403, doi:10.1029/2009 GL041009.

Whiteside MD, Treseder KK, and Atsatt PR. 2009. The brighter side of soils: quantum dots track organic nitrogen through fungi and plants. Ecology 90: 100-08.

Wise M, Calvin K, Thomson A, et al. 2009. Implications of limiting $\mathrm{CO}_{2}$ concentrations for land use and energy. Science 324: $1183-86$.

Zaehle S, Friedlingstein P, and Friend AD. 2010. Terrestrial nitrogen feedbacks may accelerate future climate change. Geophys Res Lett 37: L01401, doi:10.1029/2009GL041345.

Zhang XY, Friedl MA, Schaaf CB, et al. 2004. The footprint of urban climates on vegetation phenology. Geophys Res Lett 31: L12209, doi:10.1029/2004GL020137.

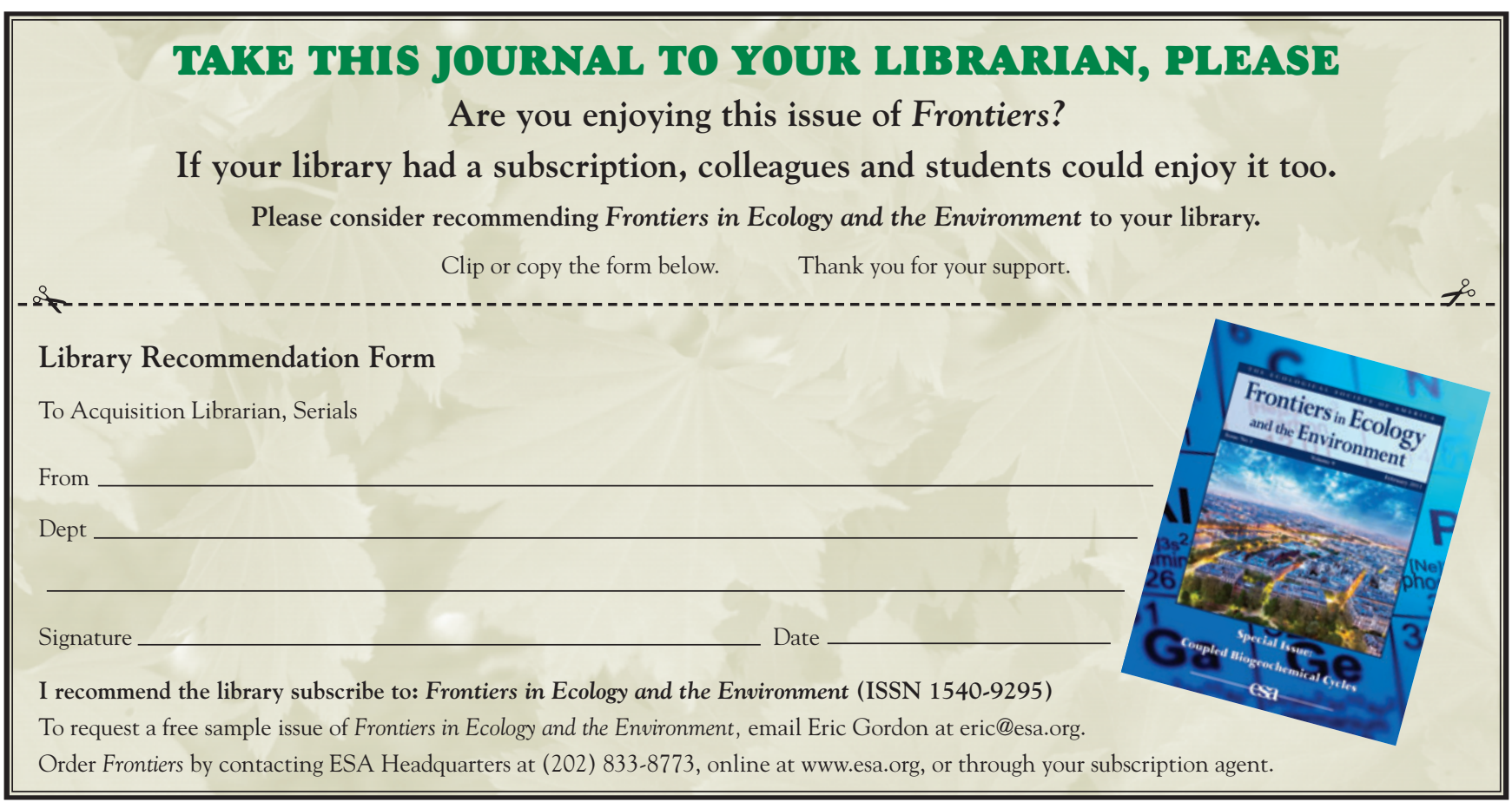

